\title{
Coral reef origins of atmospheric dimethylsulfide at Heron Island, southern Great Barrier Reef, Australia
}

\author{
Hilton B. Swan ${ }^{1,2,3}$, Graham B. Jones ${ }^{1,2}$, Elisabeth S. M. Deschaseaux ${ }^{1,2,3}$, and Bradley D. Eyre ${ }^{1,3}$ \\ ${ }^{1}$ Southern Cross University School of Environment, Science and Engineering, Lismore, New South Wales, Australia \\ ${ }^{2}$ Marine Ecology Research Centre, Southern Cross University, Lismore, New South Wales, Australia \\ ${ }^{3}$ Centre for Coastal Biogeochemistry, Southern Cross University, Lismore, New South Wales, Australia
}

Correspondence to: Hilton B. Swan (h.swan.11@scu.edu.au)

Received: 12 September 2016 - Published in Biogeosciences Discuss.: 19 September 2016

Revised: 19 December 2016 - Accepted: 21 December 2016 - Published: 17 January 2017

\begin{abstract}
Atmospheric dimethylsulfide $\left(\mathrm{DMS}_{\mathrm{a}}\right)$, continually derived from the world's oceans, is a feed gas for the tropospheric production of new sulfate particles, leading to cloud condensation nuclei that influence the formation and properties of marine clouds and ultimately the Earth's radiation budget. Previous studies on the Great Barrier Reef (GBR), Australia, have indicated coral reefs are significant sessile sources of $\mathrm{DMS}_{\mathrm{a}}$ capable of enhancing the tropospheric $\mathrm{DMS}_{\mathrm{a}}$ burden mainly derived from phytoplankton in the surface ocean; however, specific environmental evidence of coral reef DMS emissions and their characteristics is lacking. By using on-site automated continuous analysis of $\mathrm{DMS}_{\mathrm{a}}$ and meteorological parameters at Heron Island in the southern GBR, we show that the coral reef was the source of occasional spikes of $\mathrm{DMS}_{\mathrm{a}}$ identified above the oceanic $D S_{a}$ background signal. In most instances, these $D S_{a}$ spikes were detected at low tide under low wind speeds, indicating they originated from the lagoonal platform reef surrounding the island, although evidence of longer-range transport of $\mathrm{DMS}_{\mathrm{a}}$ from a $70 \mathrm{~km}$ stretch of coral reefs in the southern GBR was also observed. The most intense $\mathrm{DMS}_{\mathrm{a}}$ spike occurred in the winter dry season at low tide when convective precipitation fell onto the aerially exposed platform reef. This co-occurrence of events appeared to biologically shock the coral resulting in a seasonally aberrant extreme $\mathrm{DMS}_{\mathrm{a}}$ spike concentration of $45.9 \mathrm{nmol} \mathrm{m}^{-3}$ (1122 ppt). Seasonal DMS emission fluxes for the 2012 wet season and 2013 dry season campaigns at Heron Island were 5.0 and $1.4 \mu \mathrm{mol} \mathrm{m}{ }^{-2} \mathrm{day}^{-1}$, respectively, of which the coral reef was estimated to contribute $4 \%$ during the wet season and $14 \%$ during the dry season to the dominant oceanic flux.
\end{abstract}

\section{Introduction}

Dimethylsulfide (DMS) is the major volatile sulfur compound released from the global oceans (Andreae and Raemdonck, 1983). The primary source of DMS is dimethylsulfoniopropionate (DMSP), which is a metabolite of many marine phytoplankton (Stefels, 2000). DMSP is also present in coral tissue, its symbiotic microalgae, and coral mucus (Broadbent and Jones, 2004). When DMS diffuses from the coral biomass to the water column it is then available for exchange across the air-sea interface, which is mostly driven by wind (Ho and Wanninkhof, 2016). The shallow water column over a coral reef has a lower thermal capacity than the open ocean, so it is subject to enhanced heating by incident solar radiation (McGowan et al., 2010). This will lower the diffusivity resistance for mass transfer of DMS through the seawater surface film, as described by the Schmidt number, which is temperature dependent (Saltzman et al., 1993). This thermal effect, which can enhance the air-sea exchange of DMS (Yang et al., 2011), is expected to be pronounced during daytime low tides over coral reefs when elevated atmospheric DMS $\left(\mathrm{DMS}_{\mathrm{a}}\right)$ concentrations have been observed (Jones and Trevena, 2005). Additionally, DMS may be directly exchanged to the atmosphere from the coral surface if aerially exposed at low tide (Hopkins et al., 2016). These particular characteristics of coral reefs suggest that they could be "hotspots" for production of $\mathrm{DMS}_{\mathrm{a}}$ oxidation products contributing to the sulfate component of new aerosol particles measured from the Great Barrier Reef (GBR) (Modini et al., 2009; Vaattovaara et al., 2013). These new sulfate particles typically have hygroscopic properties that allow them to grow to a critical threshold diameter capable of acting as 
cloud condensation nuclei (CCN, $D_{p} \sim 100 \mathrm{~nm}$ ), which can produce high-albedo low-level marine clouds with numerous small droplets that efficiently scatter sunlight and reflect it back to space (Ayers and Gillett, 2000) (Fig. 1a). Since these high-albedo clouds are capable of altering incident solar radiation, it was hypothesised almost 30 years ago that biological DMS production and its subsequent air-sea exchange leading to sulfate aerosol and CCN might generate a climate feedback loop (Charlson et al., 1987); however, two decades of intensive Earth systems research has provided a lack of evidence for DMS-dominated control of CCN leading to global climate regulation (Quinn and Bates, 2011). Nevertheless, since DMS is an important trace gas that has the potential to play a significant role in the Earth's radiation budget, there is continuing interest in measuring DMS in the biosphere for the estimation of sea-to-air emission fluxes to assist climate and Earth system modelling (Lana et al., 2011).

Even though the total area of the world's coral reefs amount to $\sim 0.2 \%$ of the entire marine environment, the GBR is classed as the single largest living organism on Earth, stretching $\sim 2300 \mathrm{~km}$ along the NE coast of Australia and covering an area of $\sim 344400 \mathrm{~km}^{2}$ that can be seen from space (Hutchings et al., 2008). Considering these dimensions, the GBR is clearly a significant marine ecosystem that has been under-studied in comparison to the surface ocean for DMS production. Chamber experiments have provided evidence that Acropora spp. of branching coral can be a source of $\mathrm{DMS}_{\mathrm{a}}$ in the natural reef environment. This genus of reef-building coral, which is dominant throughout the GBR (Wild et al., 2004), has been found to liberate DMS to the headspace of sealed chambers when submersed in seawater and bubbled with air (Deschaseaux et al., 2014; Fischer and Jones, 2012). A more recent chamber study that examined Acropora coral in filtered seawater detected DMS in the chamber headspace only when the coral was visibly coated in mucus or releasing mucus strands (Swan et al., 2016a), which indicates that coral reefs are likely to be intermittent sources of $\mathrm{DMS}_{\mathrm{a}}$. There are currently insufficient data available from previous GBR DMS ${ }_{\mathrm{a}}$ field studies to environmentally assess that recent chamber observation. The few previous field studies that have measured $\mathrm{DMS}_{\mathrm{a}}$ over the GBR (Broadbent and Jones, 2006; Jones and Trevena, 2005) employed gold-wool chemi-adsorption (Barnard et al., 1982; Kittler et al., 1992), a low-frequency grab-sampling technique. While the investigators of those previous field studies reported that the GBR appears to be a significant source of $\mathrm{DMS}_{\mathrm{a}}$, their low-frequency sampling technique did not provide sufficient data to characterise coral reef DMS emissions. In this study we used an automated gas chromatograph (GC) with a higher sampling frequency to examine shortterm variations in $\mathrm{DMS}_{\mathrm{a}}$ over 2-3-week periods at a coral cay in the southern GBR. The objective of this study was to gather specific environmental evidence of coral-derived DMS emissions from the GBR and to determine the inten- sity, frequency, and significance of those reef emissions in the wet and dry seasons at the Tropic of Capricorn.

\section{Methods}

\subsection{Location and sampling procedures}

The automated GC was used to continuously measure $\mathrm{DMS}_{\mathrm{a}}$ at the Heron Island Research Station $\left(23.44^{\circ} \mathrm{S}, 151.91^{\circ} \mathrm{E}\right)$, situated $\sim 80 \mathrm{~km}$ off the east Australian coastline, in the Capricorn-Bunker Group of southern GBR reefs (Fig. 2). Heron Island lies at the western end of a surrounding $27 \mathrm{~km}^{2}$ lagoonal platform reef. The reef lagoon has a cover of $\sim 15 \%$ coral and $85 \%$ permeable carbonate sands (Eyre et al., 2013). Two campaigns were conducted, 6-20 March 2012 and 18 July to 5 August 2013, providing a comparison of $\mathrm{DMS}_{\mathrm{a}}$ in the austral warmer wet (November to March) and cooler dry (April to October) seasons that are recognised at the Tropic of Capricorn.

DMS $_{\mathrm{a}}$ was sampled through Teflon ${ }^{\mathrm{TM}}$ tubing via a highcapacity oxidant scrubber composed of $1 \% \mathrm{w} / \mathrm{v}$ sodium ascorbate and glycerol impregnated into a glass-fibre filter. The sample line intake was fixed to the roof of the research station laboratory; the intake was shielded from rain and had a clear line of sight to the reef flat $\sim 100 \mathrm{~m}$ away. Surfacelevel marine air was drawn through the sampling system at a flow rate of $\sim 260 \mathrm{~mL} \mathrm{~min}^{-1}$ using a single-stage diaphragm vacuum pump. The air was drawn into a cryogenically cooled trap (cryotrap) that was constructed by passing $1.6 \mathrm{~mm}$ diameter Teflon tubing through $\sim 50 \mathrm{~cm}$ of copper tubing of $2.0 \mathrm{~mm}$ internal diameter and bending it into a loop. A sample collection time of $14.4 \mathrm{~min}$ was used to deliver $3.72 \mathrm{~L}$ of air into the cyrotrap. This volume of air was required to concentrate sufficient $\mathrm{DMS}_{\mathrm{a}}$ for chromatographic analysis, providing a $0.1 \mathrm{nmol} \mathrm{m}^{-3}(2 \mathrm{ppt})$ limit of reporting. A custom-built autosampler controlled the movement of the cryotrap, actuation of two gas valves, and started the GC. This automated GC was fitted with a pulsed flame photometric detector (Cheskis et al., 1993) and had a cycle time of $26 \mathrm{~min}$. Specified $\mathrm{DMS}_{\mathrm{a}}$ concentrations are reported at the mid-time of the 14.4 min collection period. The relative expanded measurement uncertainty was $13 \%(k=2$ for a $95 \%$ confidence level). Calibration was achieved using permeated ethyl methyl sulfide. A complete description of the configuration, operation, calibration, and measurement uncertainty of the automated GC DMS ${ }_{\mathrm{a}}$ sampling system is reported elsewhere (Swan et al., 2015).

A wireless automatic weather station (AWS, model XC0348, Electus Distribution, Rydalmere, NSW, Australia) was mounted above the roofline of the research station laboratory within $1 \mathrm{~m}$ of the air intake used to sample $\mathrm{DMS}_{\mathrm{a}}$. This AWS provided data for wind speed (WS), wind direction (WD), rainfall, indoor and outdoor air temperature, humidity, and barometric pressure, which 

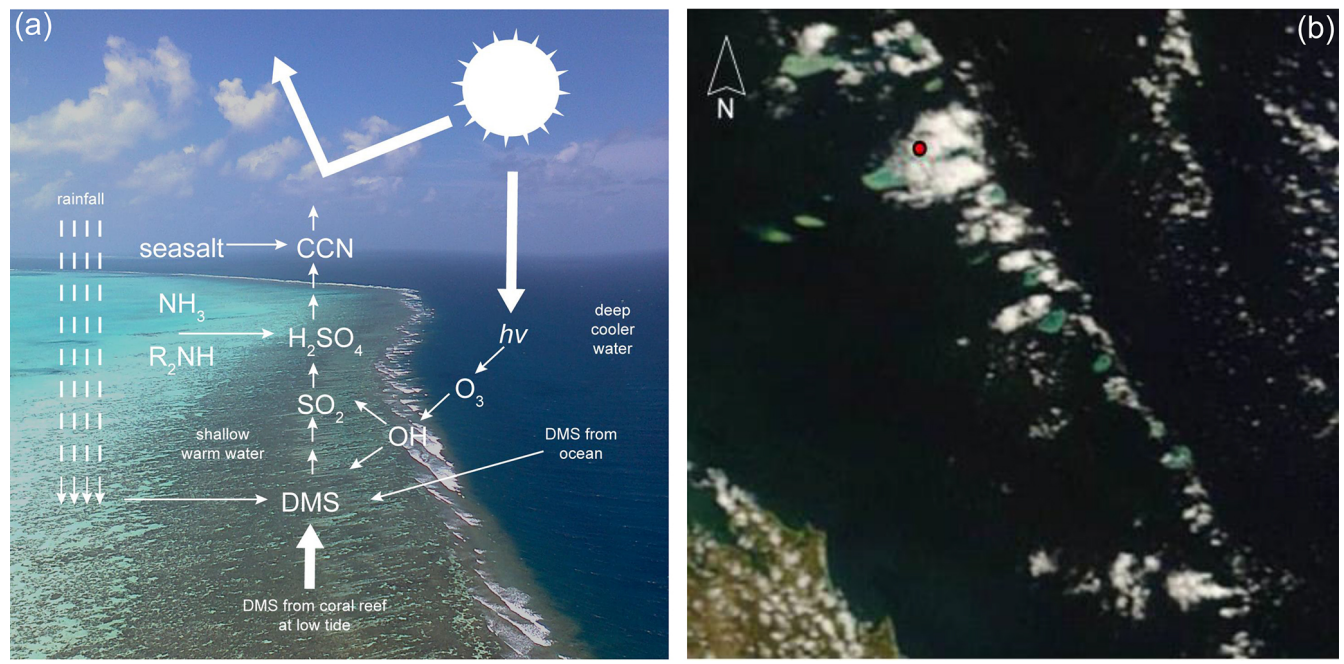

Figure 1. The Capricorn-Bunker Group of coral reefs, southern Great Barrier Reef, Australia $\left(23.13^{\circ} \mathrm{S}, 151.85^{\circ} \mathrm{E}\right.$ to $\left.23.92^{\circ} \mathrm{S}, 152.60^{\circ} \mathrm{E}\right)$. (a) An aerial photo of Wistari Reef near Heron Island (image: H. B. Swan). Superimposed on this image is a conceptual model of factors controlling $\mathrm{DMS}_{\mathrm{a}}$-derived sulfate aerosol production over the GBR. Ocean-derived $\mathrm{DMS}_{\mathrm{a}}$ and spikes of $\mathrm{DMS}_{\mathrm{a}}$ from the coral reef at low tide are oxidised by photochemically produced hydroxyl radical $(\mathrm{OH})$ forming sulfate aerosol that can grow to cloud condensation nuclei $(\mathrm{CCN})$. This process can assist formation of high-albedo low-level marine clouds that influence the radiation budget of the GBR. (b) MODIS (Moderate Resolution Imaging Spectroradiometer) satellite image of daytime low-level convective clouds aligned over the Capricorn-Bunker Group of coral reefs. Heron Island, near Wistari Reef (cloud covered), is indicated by a red circle. Part of the east Australian coastline is seen in the bottom left-hand corner.

were logged at $15 \mathrm{~min}$ intervals. The accuracy of the AWS was specified as WS $\pm 1 \mathrm{~m} \mathrm{~s}^{-1}\left(\mathrm{WS}<10 \mathrm{~m} \mathrm{~s}^{-1}\right.$ ) and $\pm 10 \%$ (WS $>10 \mathrm{~m} \mathrm{~s}^{-1}$ ), relative humidity $\pm 5 \%$, temperature $\pm 1^{\circ} \mathrm{C}$, and pressure $\pm 3 \mathrm{hPa}$. Water vapour mixing ratios were calculated from the AWS data using reported formulas (Vaisala, 2013). A pyranometer was placed on the laboratory roof next to the AWS (HOBO pendant sensor, Onset Computer Corp., Bourne, MA, USA). It logged solar irradiance (spectral range 300-1100 $\mathrm{nm}$ ) every $15 \mathrm{~min}$ and was specified by the manufacturer to have an upper light intensity limit of 323000 lumens $\mathrm{m}^{-2}$ (lux), which is equivalent to $\sim 6000 \mu \mathrm{mol} \mathrm{m}^{-2} \mathrm{~s}^{-1}$ or $3.613 \times 10^{21}$ photons $\mathrm{m}^{-2} \mathrm{~s}^{-1}$. The photon flux ( $\mu \mathrm{mol} \mathrm{m} \mathrm{m}^{-2} \mathrm{~s}^{-1}$ ) measured with this sensor was converted to radiometric energy $\left(\mathrm{J} \mathrm{m}^{-2} \mathrm{~s}^{-1}\right.$ or $\left.\mathrm{W} \mathrm{m} \mathrm{m}^{-2}\right)$ using

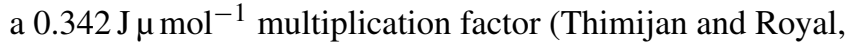
1982). To complement the AWS data, daily backward trajectory air parcel information was obtained using the NOAA Air Resources Laboratory HYSPLIT transport and dispersion model (Stein et al., 2015). Mean surface layer pressure synoptic charts at 00:00 and 12:00 UTC were also obtained from the Australian Bureau of Meteorology (BoM). Tidal information was sourced from predictions provided by the $\mathrm{Na}$ tional Tidal Unit of the Australian Bureau of Meteorology. Several site-specific observations of seawater drainage from the Heron Island reef flat showed that low tides consistently occurred $+1.25 \mathrm{~h}$ after the predicted times; tide times were adjusted accordingly. All specified dates and times are Australian Eastern Standard Time (+10 h UTC).

\subsection{Flux calculations}

Seasonal DMS emission fluxes for the wet season (14 day) and dry season (18 day) campaigns at Heron Island were calculated using the atmospheric photochemical ambient mass balance equation applied by Ayers et al. (1995) under clean marine conditions:

$\frac{\mathrm{d}[\mathrm{DMS}]}{\mathrm{d} t}=\frac{F_{\mathrm{DMS}}}{H}-K[\mathrm{OH}][\mathrm{DMS}]+\frac{E_{\mathrm{v}}\left(\left[\mathrm{DMS}_{t}\right]-[\mathrm{DMS}]\right)}{H}$

where $F_{\mathrm{DMS}}$ is the flux of DMS, [DMS] is the mean concentration of $\mathrm{DMS}_{\mathrm{a}}$ in the marine boundary layer (MBL), $\left[\mathrm{DMS}_{t}\right]$ is the concentration of $\mathrm{DMS}_{\mathrm{a}}$ in the atmospheric transition layer or entrainment zone, $E_{\mathrm{V}}$ is the MBL-lower troposphere entrainment velocity, $H$ is the mean height of the $\mathrm{MBL},[\mathrm{OH}]$ is the diurnally averaged concentration of hydroxyl radical, and $K$ is the first-order overall rate constant for reaction of $\mathrm{OH}$ with DMS. The HYSPLIT transport and dispersion model was used to obtain midday mixed layer heights, which were averaged for each season to provide input values for $H$. Seasonal contributions of the coral reef to $F_{\mathrm{DMS}}$ at Heron Island were estimated from the difference between fluxes calculated using mean and median $\mathrm{DMS}_{\mathrm{a}}$ dataset concentrations. 


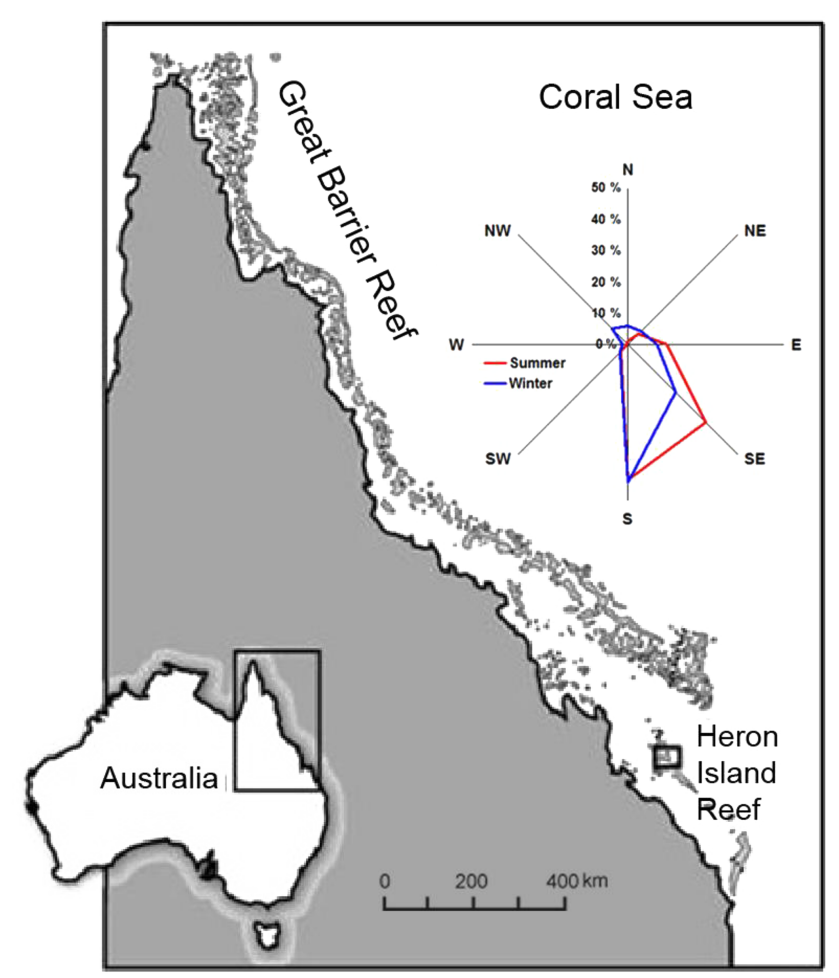

Figure 2. Location of Heron Island in the southern Great Barrier Reef, Australia, where continuous on-site analysis of $\mathrm{DMS}_{\mathrm{a}}$ was conducted in the austral wet season of 2012 and dry season of 2013. The compass shows the directional frequency of winds received at Heron Island during the late summer wet season (red line) and midwinter dry season (blue line) measurement campaigns. Daily backward trajectory analysis showed that marine-derived air streams in the SE sector were received at Heron Island the majority of the time during both campaigns.

\section{Results and discussion}

\subsection{Wet season 2012}

Here we describe four instances of clearly observed $\mathrm{DMS}_{\mathrm{a}}$ spikes in the dataset of results obtained during the wet season campaign. Meteorological conditions, tidal information, and air parcel back trajectories are examined to provide detailed information of the circumstances leading to these $\mathrm{DMS}_{\mathrm{a}}$ spikes. These spikes were superimposed on the oceanic background $\mathrm{DMS}_{\mathrm{a}}$ signal derived from phytoplankton and other pelagic marine biota. This background signal was observed as a continuum coupled to WS (Fig. 3a), which provides kinetic energy for factors that directly drive DMS air-sea exchange such as turbulence and micro-breaking waves (Huebert et al., 2010). However, the four distinct spikes of $\mathrm{DMS}_{\mathrm{a}}$ (10, 14, 16-17 March) were notably uncoupled from WS, suggesting that they were derived from a source other than the open ocean. By closely examining the environmental conditions when each $\mathrm{DMS}_{\mathrm{a}}$ spike was detected it was possible to attribute three of these intermittent spikes to DMS emissions from the platform reef surrounding Heron Island. In these instances, each spike was detected at low tide under WS of $<2 \mathrm{~m} \mathrm{~s}^{-1}$, indicating that the prevailing SE trade winds (Fig. 2) acted as a diluent to disperse plumes of $\mathrm{DMS}_{\mathrm{a}}$ emitted from the coral reef. It is, therefore, likely that the SE trade winds masked other instances of DMS emissions from the platform reef by diluting the $\mathrm{DMS}_{\mathrm{a}}$ to the point that it was indistinguishable from the oceanic background $\mathrm{DMS}_{\mathrm{a}}$ signal. The circumstances surrounding the largest wet season $\mathrm{DMS}_{\mathrm{a}}$ spike on 16 March (Fig. 3a) were unique, suggesting that it resulted from longer-range transport of $\mathrm{DMS}_{\mathrm{a}}$ derived from the Capricorn-Bunker Group of coral reefs to the SE of Heron Island (Fig. 1b). We saw no evidence of coral bleaching on the Heron Island platform reef during the summer wet season of 2012 to affect its usually high biodiversity. Complementary measurements of DMSP concentrations in Acropora aspera branching coral growing on the Heron Island reef flat in March 2012 indicated that the coral reef was in good health and not temperature stressed (Swan et al., 2016b).

The first of the $\mathrm{DMS}_{\mathrm{a}}$ spikes indicated to be derived from the platform reef surrounding Heron Island was detected on 10 March between 03:33 and 06:08 under low WS of 0$0.7 \mathrm{~m} \mathrm{~s}^{-1}$. In the early morning of the 10 March back trajectories show that high-altitude $(+1000 \mathrm{~m})$ continental air was directed to Heron Island (Fig. 4). This dry free-tropospheric non-marine air flow was characterised by a rapid drop in the water vapour mixing ratio from 17.4 to $13.0 \mathrm{~g} \mathrm{~kg}^{-1}$, and also resulted in the lowest $\mathrm{DMS}_{\mathrm{a}}$ wet season concentration of $0.6 \mathrm{nmol} \mathrm{m}{ }^{-3}$ which occurred shortly after high tide under calm conditions. As the tide dropped, the $\mathrm{DMS}_{\mathrm{a}}$ steadily increased, and in the period 10 March 03:59 to 05:42 the anemometer was becalmed. Between 03:07 and 03:33 the $\mathrm{DMS}_{\mathrm{a}}$ rapidly increased from 2.1 to $6.2 \mathrm{nmol} \mathrm{m}^{-3}$ and, thereafter, five consecutive $\mathrm{DMS}_{\mathrm{a}}$ concentrations of $\sim 6 \mathrm{nmol} \mathrm{m}^{-3}$ were recorded over a period of nearly $2 \mathrm{~h}$ when WS was $0 \mathrm{~m} \mathrm{~s}^{-1}$. The low tide at 04:50 occurred near the middle of this period of no air movement. A peak $\mathrm{DMS}_{\mathrm{a}}$ concentration of $6.4 \mathrm{nmol} \mathrm{m}^{-3}$ was recorded at $05: 16$; however, it decreased to $2.6 \mathrm{nmol} \mathrm{m}^{-3}$ by 07:00 with the onset of a southerly change at 06:36, when WS sharply increased from 0.3 to $2.4 \mathrm{~m} \mathrm{~s}^{-1}$. The WS continued to increase in strength, and by 10 March 07:26 $\mathrm{DMS}_{\mathrm{a}}$ had returned to the background concentration of $2.2 \mathrm{nmol} \mathrm{m}^{-3}$ (Fig. 3b). These observations indicate that the relatively low WS of $2.4 \mathrm{~m} \mathrm{~s}^{-1}$ was sufficient to rapidly dilute the DMS plume with marine air containing less $\mathrm{DMS}_{\mathrm{a}}$. The meteorological conditions under which this $\mathrm{DMS}_{\mathrm{a}}$ spike occurred provide compelling evidence that it was a point source emission derived from the lagoonal platform reef surrounding Heron Island.

The second $\mathrm{DMS}_{\mathrm{a}}$ spike was observed on 14 March at 21:12, which resulted in a peak $\mathrm{DMS}_{\mathrm{a}}$ concentration of $10.6 \mathrm{nmol} \mathrm{m}^{-3}$. This $\mathrm{DMS}_{\mathrm{a}}$ spike appeared to result from rain enhanced air-sea exchange of DMS from the Heron Island reef flat at low tide. The increase in $\mathrm{DMS}_{\mathrm{a}}$ began in 

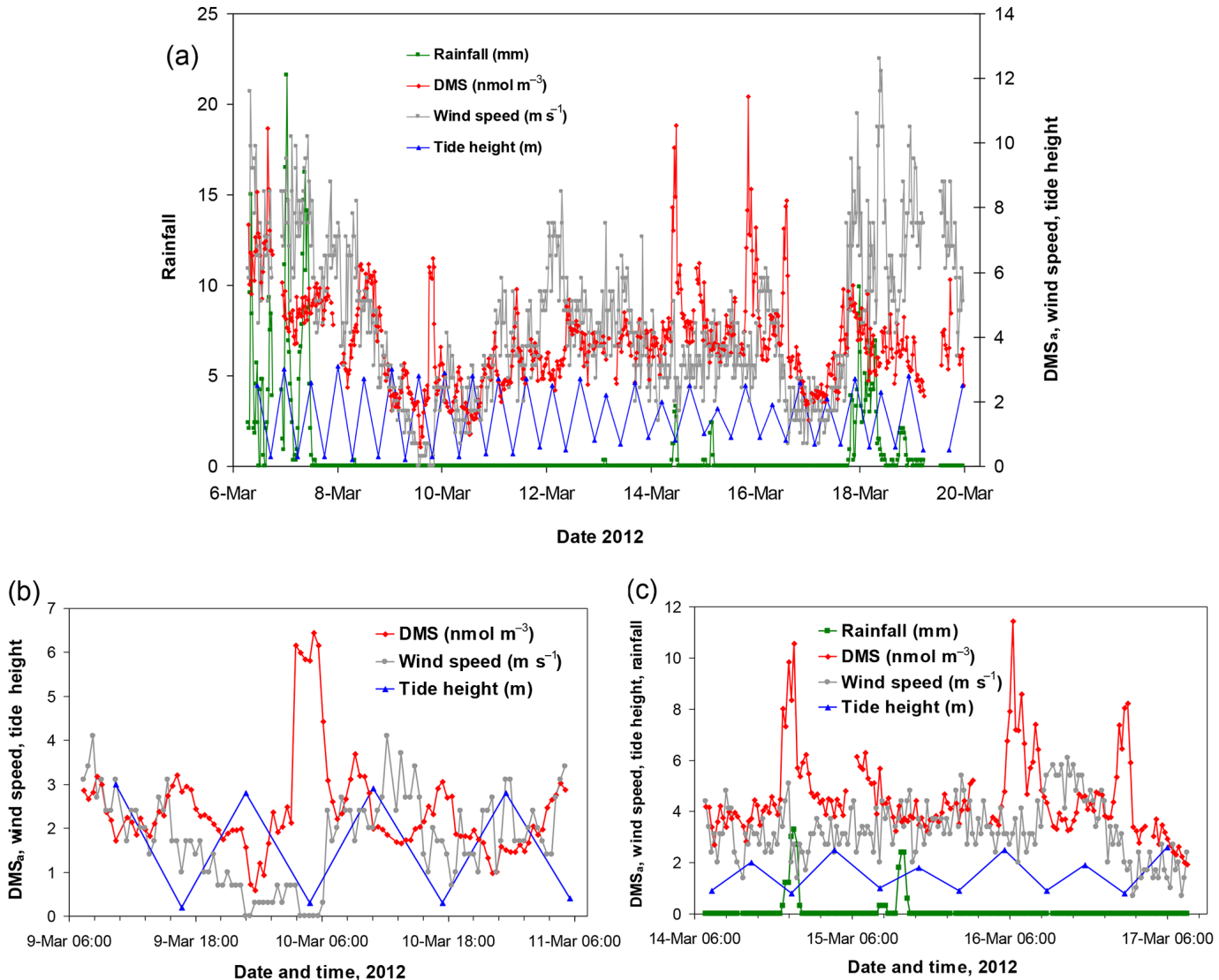

Figure 3. Data obtained from Heron Island during the wet season of 2012. (a) Entire time series of DMS (red line), wind speed (WS, grey line), rainfall (green line), and tide height (blue line). Four distinct spikes $\left(10,14,16-17\right.$ March) above the background DMS $\mathrm{a}_{\mathrm{a}}$ signal are indicated to be coral-reef-derived emissions. (b) Extracted time series showing the $\mathrm{DMS}_{\mathrm{a}}$ spike on 10 March (red line), which occurred during a $0.3 \mathrm{~m}$ low tide under still conditions (grey line). There was no rainfall during the period shown. (c) Extracted time series showing three distinct coral reef DMS $\mathrm{a}_{\mathrm{a}}$ spikes. The first, detected between 21:12 on 14 March and 01:05 on 15 March ( $\sim$ h duration), was associated with convective rainfall (green line) during a $0.8 \mathrm{~m}$ low tide. The highest $\mathrm{DMS}_{\mathrm{a}}$ concentration recorded during the wet season campaign $\left(11.5 \mathrm{nmol} \mathrm{m}^{-3}\right)$ was detected on $16 \mathrm{March}$ at $06: 27$, shortly after high tide. This tidally unique and longest-lasting DMS $\mathrm{D}_{\mathrm{a}}$ spike $(\sim 8.5 \mathrm{~h})$ is indicated to have originated from low-level marine air that traversed the length of the $70 \mathrm{~km}$ Bunker Group of coral reefs that lie to the SE of Heron Island (Fig. 1b). The third DMS a spike seen on 17 March, which occurred on a $0.8 \mathrm{~m}$ low tide under abating WS, is indicated to be derived from the lagoonal platform reef surrounding Heron Island.

the evening at 19:02 and returned to the background level at midnight. At the start of this event the WS was between 3 and $4 \mathrm{~m} \mathrm{~s}^{-1}$, and the background oceanic-derived $\mathrm{DMS}_{\mathrm{a}}$ was $\sim 4 \mathrm{nmol} \mathrm{m}^{-3}$. There had been no rain during the day; however, between 19:28 and 22:04 a local convection-generated storm delivered a total of $12 \mathrm{~mm}$ of precipitation which fell during a $0.8 \mathrm{~m}$ low tide. The $\mathrm{DMS}_{\mathrm{a}}$ rose sharply from 3.9 to $10.6 \mathrm{nmol} \mathrm{m}^{-3}$ in a $2.5 \mathrm{~h}$ period as a result of these two simultaneous events. Three steps were observed in this $\mathrm{DMS}_{\mathrm{a}}$ spike and appeared to be linked to variations in rainfall intensity and WS. After the onset of the rainfall there was a pause in the rain and the WS increased to $5.1 \mathrm{~m} \mathrm{~s}^{-1}$, resulting in a pause in the rise of $\mathrm{DMS}_{\mathrm{a}}$; the WS then dropped to $2 \mathrm{~m} \mathrm{~s}^{-1}$ as the precipitation intensity increased, resulting in the next rise in the $\mathrm{DMS}_{\mathrm{a}}$ spike. When the rainfall was most intense the WS had dropped to $1.4 \mathrm{~m} \mathrm{~s}^{-1}$ and this resulted in the peak DMS ${ }_{\mathrm{a}}$ concentration which also occurred at the tidal minimum. As the rain eased, the WS again increased and the $\mathrm{DMS}_{\mathrm{a}}$ concentration rapidly decreased with the rising tide, returning to the background concentration of $4.3 \mathrm{nmol} \mathrm{m}^{-3}$ at 01:05 on $15 \mathrm{March}$. This combination of a $0.8 \mathrm{~m}$ low tide coupled with a $2.5 \mathrm{~h}$ convective rainfall event resulted in an increase of $6 \mathrm{nmol} \mathrm{m}^{-3}$ above the prevailing background ocean $\mathrm{DMS}_{\mathrm{a}}$ signal. The peak $\mathrm{DMS}_{\mathrm{a}}$ concentration which co-occurred with the lowest recorded WS was apparently due to reduced mixing of the rain-enhanced local $\mathrm{DMS}_{\text {a }}$ plume from the reef with background marine air containing less $\mathrm{DMS}_{\mathrm{a}}$. Later, on 15 March between 12:40 and 14:50, another local convection storm delivered $7.2 \mathrm{~mm}$ of rain under a higher average WS of $\sim 4 \mathrm{~m} \mathrm{~s}^{-1}$. This later rain 


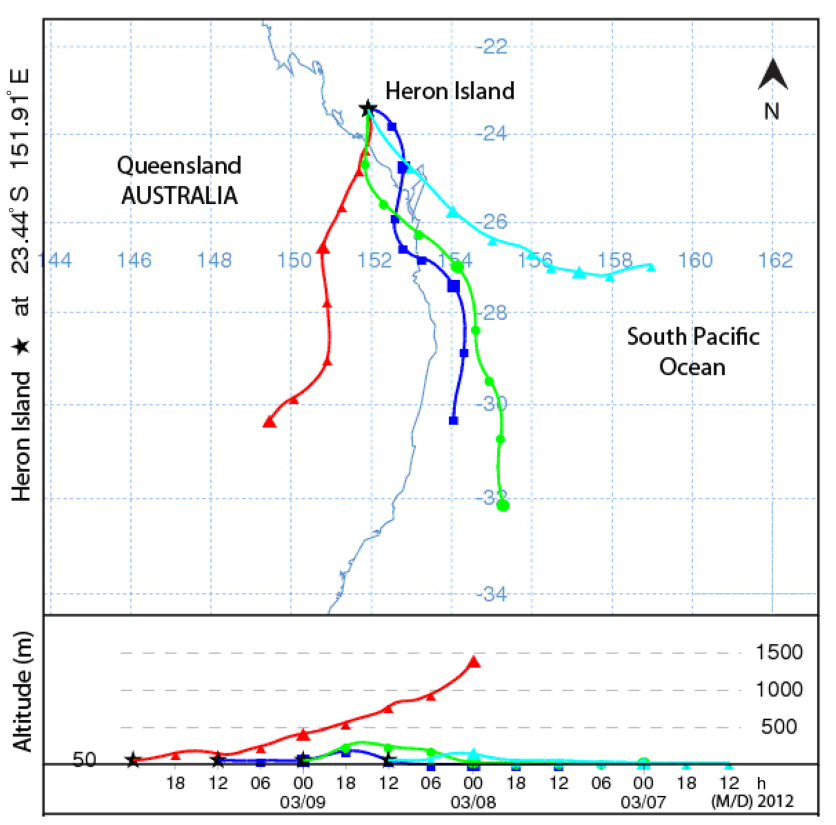

Figure 4. Twelve-hour separated back trajectories of $48 \mathrm{~h}$ duration ending 10 March 2012 showing air movement onto the Australian continent with high-altitude free-tropospheric air (red line) being directed to Heron Island. This relatively dry non-marine air stream resulted in the lowest $\mathrm{DMS}_{\mathrm{a}}$ concentration of $0.6 \mathrm{nmol} \mathrm{m}^{-3}$ during the wet season campaign, which occurred shortly after high tide. However, by low tide a $\mathrm{DMS}_{\mathrm{a}}$ spike peaking at $6.4 \mathrm{nmol} \mathrm{m}^{-3}$ was detected in this air stream under calm conditions (Fig. 3b) prior to a southerly change that redirected the usual marine air flow. The tidal and meteorological conditions under which this $\mathrm{DMS}_{\mathrm{a}}$ spike was detected strongly suggest that it was derived from the coral reef surrounding Heron Island.

event did not coincide with low tide and did not induce a detectable DMS $\mathrm{a}_{\mathrm{a}}$ spike from the Heron Island reef flat (Fig. 3c).

The third $\mathrm{DMS}_{\mathrm{a}}$ spike during the wet season was detected on 16 March at 06:27, resulting in the highest recorded concentration of $11.5 \mathrm{nmol} \mathrm{m}^{-3}$ in the wet season dataset. This DMS $\mathrm{a}_{\mathrm{a}}$ spike lasted for $8.4 \mathrm{~h}$, was a factor of 3.3 above the oceanic background level at its peak, and according to back trajectories occurred during a low-elevation marine air stream from a SE direction (Fig. 5). Unlike previous observations, this $\mathrm{DMS}_{\mathrm{a}}$ spike started on a $2.5 \mathrm{~m}$ high tide and was rapidly decreasing by the time of the following $0.9 \mathrm{~m}$ low tide. WS data indicated that the $\mathrm{DMS}_{\mathrm{a}}$ spike was not derived from wind enhanced air-sea exchange because $\mathrm{DMS}_{\mathrm{a}}$ increased from 3.5 to $11.5 \mathrm{nmol} \mathrm{m}^{-3}$ as the WS eased from 4.1 to $3.1 \mathrm{~m} \mathrm{~s}^{-1}$, and the $\mathrm{DMS}_{\mathrm{a}}$ peak returned to the background $\mathrm{DMS}_{\mathrm{a}}$ level as the WS increased from 3.4 to $5.8 \mathrm{~m} \mathrm{~s}^{-1}$ (Fig. 3c). According to back trajectories at that time the source of this long-lasting maximum $\mathrm{DMS}_{\mathrm{a}}$ spike in the wet season dataset is suspected to have originated from air that traversed the Capricorn-Bunker Group, an extensive array of coral reefs to the SE of Heron Island that span a

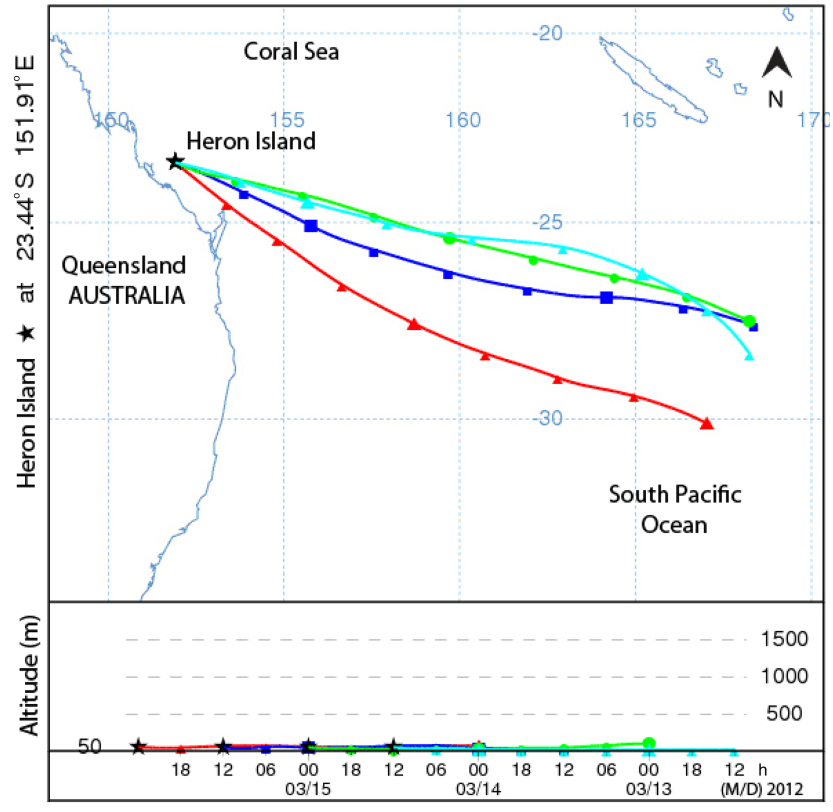

Figure 5. Twelve-hour separated back trajectories of $48 \mathrm{~h}$ duration ending 16 March 2012 showing the low-level SE marine air flow (red line) that is indicated to have traversed the $\sim 70 \mathrm{~km}$ length of Capricorn-Bunker Group of coral reefs (Fig. 1b) before arriving at Heron Island. This marine air flow resulted in the longest lasting $\mathrm{DMS}_{\mathrm{a}}$ spike and the highest recorded $\mathrm{DMS}_{\mathrm{a}}$ concentration of $11.5 \mathrm{nmol} \mathrm{m}^{-3}$ during the wet season campaign (Fig. 3c).

distance of $\sim 70 \mathrm{~km}$ (Fig. 1b). This observation supports a previous report of elevated $\mathrm{DMS}_{\mathrm{a}}$ in SE trade winds that travelled over dense coral biomass areas of the GBR and western Pacific Ocean (Jones and Trevena, 2005). Additionally, at a Queensland coastal site $\left(24.21^{\circ} \mathrm{S}, 151.90^{\circ} \mathrm{E}\right)$ elevated new particle number concentrations, reflecting a strong nucleation event, were detected in an air stream that travelled over the Capricorn-Bunker Group of southern GBR reefs on 30 March 2007 (Modini et al., 2009).

The fourth $\mathrm{DMS}_{\mathrm{a}}$ spike, which occurred between 21:20 16 March and 00:48 17 March (3.5 h duration), was observed as the WS abated from 3.4 to $0.7 \mathrm{~m} \mathrm{~s}^{-1}$, indicating that it did not result from increased air-sea exchange. The background $\mathrm{DMS}_{\mathrm{a}}$ signal before and after this spike was, however, clearly decreasing with the abating WS (Fig. 3c). The peak DMS $\mathrm{a}_{\mathrm{a}}$ concentration of $8.2 \mathrm{nmol} \mathrm{m}^{-3}$ occurred at midnight on a $0.8 \mathrm{~m}$ low tide under a low WS of $1.7 \mathrm{~m} \mathrm{~s}^{-1}$. These meteorological conditions again implicate the reef flat surrounding Heron Island as the source of this $\mathrm{DMS}_{\mathrm{a}}$ spike, which was detected under relatively calm conditions when the water level over the reef was low.

\subsection{Dry season 2013}

During the dry season campaign at Heron Island, spring tides were experienced from 18 to 24 July with low-tide heights 
ranging from -0.1 to $0.3 \mathrm{~m}$. During these particularly low tides 10 clearly defined $\mathrm{DMS}_{\mathrm{a}}$ spikes of varying magnitude were observed above the background oceanic $\mathrm{DMS}_{\mathrm{a}}$ signal. Three of these spikes were detected in WS exceeding $5 \mathrm{~m} \mathrm{~s}^{-1}$, which suggests that they were intense emission events from the lagoonal platform reef. An extreme $\mathrm{DMS}_{\mathrm{a}}$ spike was detected in the early evening of $25 \mathrm{July}$, when a convection storm deposited only $1.8 \mathrm{~mm}$ of rainfall onto the Heron Island reef flat when much of it was aerially exposed by a spring low tide of $0.2 \mathrm{~m}$. Under this scenario, the background $\mathrm{DMS}_{\mathrm{a}}$ concentration of $1.4 \mathrm{nmol} \mathrm{m}^{-3}$ at 17:26 increased to $45.9 \mathrm{nmol} \mathrm{m}^{-3}$ (1122 ppt) by 17:50 (Fig. 6a, b). This rain-reef-atmosphere interaction was characterised by a strong odour of DMS, and to our knowledge is the highest $\mathrm{DMS}_{\mathrm{a}}$ concentration measured over a coral reef. It was also the sharpest $\mathrm{DMS}_{\mathrm{a}}$ spike detected during both campaigns, with the $\mathrm{DMS}_{\mathrm{a}}$ returning to the background level within $1 \mathrm{~h}$. This $45.9 \mathrm{nmol} \mathrm{m}^{-3} \mathrm{DMS}_{\text {a }}$ peak concentration occurred under a low rain rate $\left(1.5 \mathrm{~mm} \mathrm{~h}^{-1}\right)$ and one of the highest WS $\left(9.5 \mathrm{~m} \mathrm{~s}^{-1}\right)$ measured during the dry season campaign. At this WS rain effects on air-water gas exchange are minor (Harrison et al., 2012) and cannot account for the sudden intensity of $\mathrm{DMS}_{\mathrm{a}}$ observed. Since physical reasons alone cannot explain this extreme $\mathrm{DMS}_{\mathrm{a}}$ spike, we propose that rainfall onto the aerially exposed coral reef induced a biological shock, where the coral reacted to a rapid decline in seawater salinity by utilising intracellular DMSP to maintain osmotic pressure balance and to cope with the associated rapid decline in temperature (Stefels, 2000, and references therein). DMSP is recognised as an osmotically active intracellular compatible solute in unicellular algae that may act to buffer cell volume changes during the initial period after an osmotic shock (Kirst, 1996). Since unicellular algae (zooxanthellae) are abundant within the coral symbiosis, it is likely that corals use DMSP for osmotic regulation. Utilisation of DMSP, a sulfonium zwitterion, for osmotic pressure balance could generate significant quantities of DMS as a metabolic by-product resulting in the extreme $\mathrm{DMS}_{\mathrm{a}}$ spike observed, even under strong atmospheric mixing. It is suspected that the brevity of this DMS $\mathrm{a}_{\mathrm{a}}$ spike was because DMS was directly exchanged to the atmosphere from aerially exposed coral on the very low tide and was rapidly diluted by horizontal advection under strong winds.

\subsection{Estimation of seasonal DMS flux}

During both campaigns at Heron Island, daily backward trajectory air parcel analysis showed that clean marine air flows were received the majority of the time. Occasionally, when air was received from over the Australian continent, it was derived from high altitude $(+1000 \mathrm{~m})$, and was indicated to be clean free-tropospheric air. These conditions support use of the applied photochemical ambient mass balance Eq. (1), which specifies that $\mathrm{DMS}_{\mathrm{a}}$ is predominantly removed from the clean MBL by reaction with $\mathrm{OH}$. In polluted regions, where significant concentrations of $\mathrm{NO}_{3}$ are often present, it is necessary to include $\mathrm{NO}_{3}$, another DMS oxidant, in the mass balance equation used to determine DMS flux (Chen et al., 1999; Shon et al., 2005). Equation (1) balances factors that alter mean concentrations of DMS $_{\mathrm{a}}$ over time within seasonal average MBL box volumes. The MBL is composed of the surface layer, immediately above the sea, and the mixed layer (sub-cloud layer); it is through these layers that the ocean and the atmosphere are coupled. The mixed layer is capped by a transition layer that is $\sim 100$ to $200 \mathrm{~m}$ deep over tropical oceans (Johnson et al., 2001). This zone, often referred to as the entrainment zone, is characterised by a decrease in humidity together with a sharp increase in stability leading into the free troposphere (Clarke et al., 1998).

Mean concentrations of $\mathrm{DMS}_{\mathrm{a}}$ measured in this study were $1.3(1 \sigma=1.6, n=923)$ and $3.9 \mathrm{nmol} \mathrm{m}^{-3}(1 \sigma=1.5$, $n=651$ ) for the dry and wet seasons, respectively (Table 1). The number of DMS ${ }_{\mathrm{a}}$ measurements is sufficiently large that these mean concentrations for each campaign are expected to be representative of $\mathrm{DMS}_{\mathrm{a}}$ in the MBL over Heron Island during the wet and dry seasons. The concentration of $\mathrm{DMS}_{\mathrm{a}}$ in the entrainment zone is reported to be typically $\sim 10 \%$ of the MBL concentration (Ayers et al., 1995; Chen et al., 1999), so this percentage was applied to determine $\left[\mathrm{DMS}_{t}\right]$. The sensitivity of this variable in Eq. (1) is low; when values for $\left[\mathrm{DMS}_{t}\right]$ of 5 and $20 \%$ of MBL concentrations are entered into Eq. (1), $F_{\mathrm{DMS}}$ varies by only $1.4-2.6 \%$. Average mixed layer heights (MLHs) at noon were $977 \mathrm{~m}( \pm 231 \mathrm{~m}$, range 680 to $1460 \mathrm{~m}, n=15$ days $)$ and $786 \mathrm{~m}( \pm 290 \mathrm{~m}$, range 346 to $1312 \mathrm{~m}, n=19$ days) during the 2012 wet season and 2013 dry season campaigns, respectively. These average values are consistent with a study of the MLH at Heron Island in June 2009 and February 2010, which ranged from 375 to $1200 \mathrm{~m}$ above the surface (MacKellar et al., 2013). Maximum MLHs were observed under stable anticyclone conditions, while minimum MLHs were observed during periods of heavy precipitation with convective downdrafts. Given that the MLH is the major part of the MBL, which is typically around 700 to $800 \mathrm{~m}$ (Stull, 1988), the average MLH values of $977 \mathrm{~m}$ (wet season) and $786 \mathrm{~m}$ (dry season) were, therefore, applied for $H$ in Eq. (1). We were unable to measure the other input variables for Eq. (1) so representative values for the study location were derived from the literature. A value of $0.004 \mathrm{~m} \mathrm{~s}^{-1}$ was applied for $E_{\mathrm{v}}$ according to average data obtained from Lagrangian experiments in the Southern Hemisphere remote MBL (Wang et al., 1999). The entrainment rate from the lower troposphere into the MBL is typically low, and when $E_{\mathrm{v}}$ is varied by $\pm 100 \%$ in Eq. (1) it has a sensitivity effect of $12-19 \%$ on $F_{\text {DMS }}$. A value of $6.5 \times 10^{-12} \mathrm{~cm} \mathrm{molecule}^{-1} \mathrm{~s}^{-1}$ was applied for $K$, which is the sum of the abstraction and addition rate reactions of $\mathrm{OH}$ with DMS at $25^{\circ} \mathrm{C}$ and $1 \mathrm{~atm}$ (Finlayson-Pitts and Pitts Jr., 2000), which represents the temperature and pressure during the campaigns. The major variable altering $\mathrm{OH}$ concentrations in the atmosphere is the intensity of solar UV-B radi- 


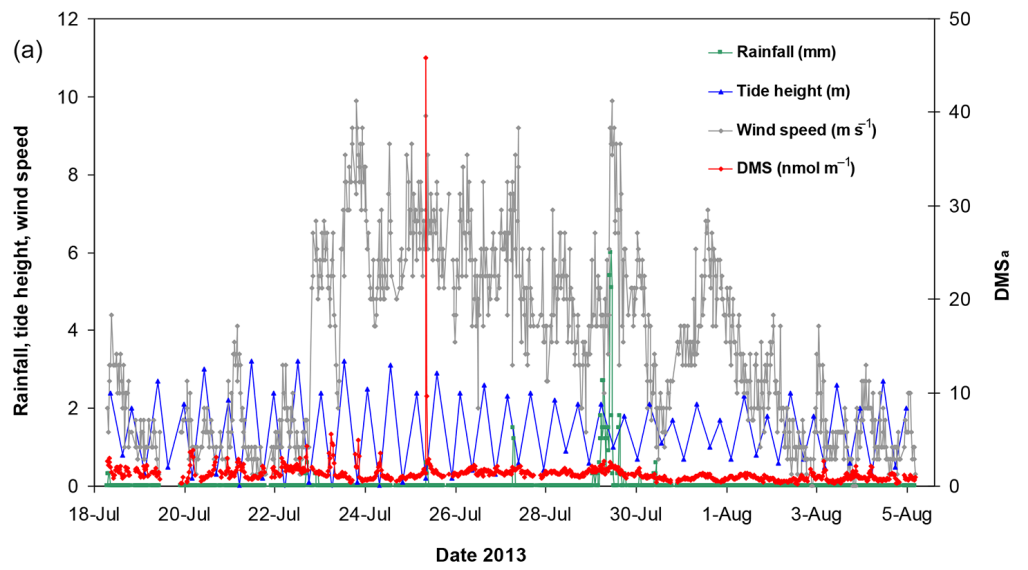

(b)

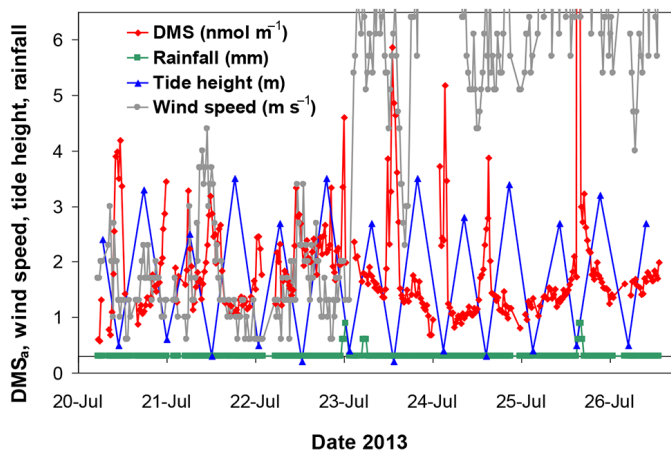

(c)

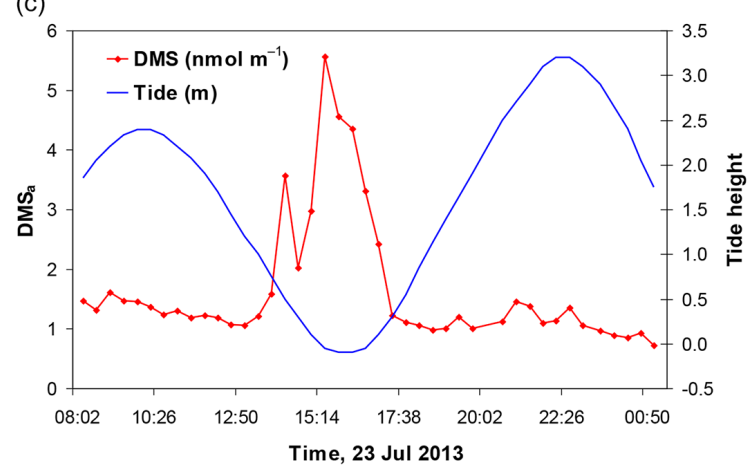

Figure 6. Data obtained from Heron Island during the dry season of 2013. (a) Entire time series of DMS (red line), WS (grey line), rainfall (green line) and tide height (blue line). The second axis for $\mathrm{DMS}_{\mathrm{a}}$ is scaled to show the relative intensity of the coral reef $\mathrm{DMS}_{\mathrm{a}}$ spike $\left(45.9 \mathrm{nmol} \mathrm{m}^{-3}\right)$ detected at low tide in the early evening of 25 July. Even under relatively strong atmospheric mixing (WS $=9.5 \mathrm{~m} \mathrm{~s}-1$, grey line) this $\mathrm{DMS}_{\mathrm{a}}$ reef-derived spike was detected as an intense event. (b) Extracted time series from 20 to 26 July showing 10 low-tide coupled DMS $\mathrm{S}_{\mathrm{a}}$ spikes from the Heron Island reef flat. The extreme $\mathrm{DMS}_{\mathrm{a}}$ spike (off-scale) on 25 July can be seen to be linked to the $0.2 \mathrm{~m}$ low tide and a brief shower of rain that fell onto the aerially exposed coral reef. (c) Time-line magnification of the low-tide-induced DMS spike from the Heron Island coral reef on 23 July between 13:31 and 17:28. There was no rainfall during the period shown.

ation, which controls the generation of $\mathrm{OH}$ from the photolysis of ozone (Rohrer and Berresheim, 2006). At Heron Island on the Tropic of Capricorn, the average daily solar irradiance measured at the surface during the 2013 winter dry season was only $10 \%$ lower than during the 2012 wet season campaign (Table 1). According to this seasonal variation in surface solar irradiance and reported average $\mathrm{OH}$ concentrations over the South Pacific Ocean (Seinfeld and Pandis, 1998), values for $[\mathrm{OH}]$ of $1.8 \times 10^{6}$ (wet season) and $1.6 \times 10^{6}$ molecules $\mathrm{cm}^{-3}$ (dry season) were applied to Eq. (1).

Solving Eq. (1) for $F_{\mathrm{DMS}}$ using the mean $\mathrm{DMS}_{\mathrm{a}}$ concentrations and other specified values gave surface fluxes of 5.0 and $1.4 \mu \mathrm{mol} \mathrm{m}{ }^{-2}$ day $^{-1}$ for the wet and dry season campaigns, respectively. These fluxes were clearly dominated by the oceanic background $\mathrm{DMS}_{\mathrm{a}}$ source; they reflect expected seasonal surface ocean primary productivity and are temporally and spatially consistent with predicted fluxes calculated from a database of global surface ocean DMS concentrations
(Lana et al., 2011). These seasonal fluxes, calculated using the photochemical mass balance approach, are expected to have a relative uncertainty of $\sim 50 \%$ (Chen et al., 1999). The highest $\mathrm{DMS}_{\mathrm{a}}$ concentrations in both seasonal datasets could be attributed to coral reef emissions. This was most apparent in the dry season dataset (Fig. 6), where the relatively stable oceanic background $\mathrm{DMS}_{\mathrm{a}}$ signal was occasionally elevated by spikes of $\mathrm{DMS}_{\mathrm{a}}$ from the Heron Island reef flat at low tide. In both seasons the reef spikes positively skewed the dataset distributions, resulting in larger mean values than median values. If median $\mathrm{DMS}_{\mathrm{a}}$ concentrations (Table 1) are instead entered into Eq. (1), $F_{\text {DMS }}$ equates to 4.8 and $1.2 \mu \mathrm{mol} \mathrm{m}^{-2} \mathrm{day}^{-1}$ for the wet and dry season campaigns, respectively. Entering median $\mathrm{DMS}_{\mathrm{a}}$ concentrations into Eq. (1) provides an estimate of the oceanic flux in both seasons since the median values act to negate the contribution from the coral reef $\mathrm{DMS}_{\mathrm{a}}$ spikes. The difference between $F_{\text {DMS }}$ calculated using mean and median values for [DMS] equates to $0.2 \mu \mathrm{mol} \mathrm{m}^{-2} \mathrm{day}^{-1}$ for both the wet and dry sea- 
Table 1. Summary of atmospheric DMS and some meteorological data for the 2012 wet season and 2013 dry season campaigns at Heron Island, southern Great Barrier Reef.

\begin{tabular}{|c|c|c|c|c|c|c|c|c|c|c|}
\hline \multirow[b]{2}{*}{ Season } & \multicolumn{2}{|c|}{$\begin{array}{c}\text { Atmospheric DMS } \\
\mathrm{nmol} \mathrm{m}^{-3} \text { (ppt) }\end{array}$} & \multicolumn{2}{|c|}{$\begin{array}{l}\text { Wind speed } \\
\mathrm{m} \mathrm{s}^{-1}\end{array}$} & \multicolumn{2}{|c|}{$\begin{array}{l}\text { Air temp } \\
{ }^{\circ} \mathrm{C}\end{array}$} & \multicolumn{2}{|c|}{$\begin{array}{l}\text { Water vapour } \\
\text { mixing ratio } \\
\mathrm{g} \mathrm{kg}^{-1}\end{array}$} & \multicolumn{2}{|c|}{$\begin{array}{c}\text { Daily solar } \\
\text { irradiance }^{\mathrm{a}} \\
\mathrm{MJ} \mathrm{m}^{-2} \text { day }^{-1}\end{array}$} \\
\hline & Wet & Dry & Wet & Dry & Wet & Dry & Wet & Dry & Wet & Dry \\
\hline Mean & $3.9(95)^{b}$ & $1.3(32)^{\mathrm{c}}$ & $4.5^{\mathrm{d}}$ & $3.5^{\mathrm{e}}$ & 26.5 & 20.8 & 17.3 & 8.9 & 27.4 & 24.7 \\
\hline SD & $1.5(37)$ & $1.6(39)$ & 2.4 & 2.3 & 1.7 & 2.2 & 1.6 & 2.2 & 10.6 & 8.6 \\
\hline Median & $3.7(90)$ & $1.2(29)$ & 4.1 & 3.3 & 26.0 & 20.4 & 17.6 & 9.2 & 32.0 & 28.3 \\
\hline Minimum & $0.6(15)$ & $0.2(5)$ & 0 & 0 & 22.7 & 15.6 & 12.8 & 2.2 & 4.7 & 5.0 \\
\hline Maximum & $11.5(281)$ & $45.9(1122)$ & 13.6 & 9.9 & 32.6 & 29.0 & 20.8 & 13.2 & 37.2 & 33.2 \\
\hline
\end{tabular}

${ }^{a}$ Daily solar irradiance is for the $24 \mathrm{~h}_{\text {period. }}{ }^{\mathrm{b}}$ The number of DMS measurements for the 2012 wet season campaign was $651 .{ }^{\mathrm{c}}$ The number of DMS measurements for the 2013 dry season campaign was $923 .{ }^{\mathrm{d}}$ The number of meteorological observations for the 2012 wet season campaign was $1313 .{ }^{\mathrm{e}}$ The number of meteorological observations for the 2013 dry season campaign was 1716 .

son campaigns, thereby providing an estimate of the previously unquantified contribution of the coral reef to $F_{\mathrm{DMS}}$ at Heron Island. When this $0.2 \mu \mathrm{mol} \mathrm{m}{ }^{-2}$ day $^{-1}$ coral reef flux estimate is expressed as a fraction of the overall $F_{\mathrm{DMS}}$ in each season, it is apparent that the coral reef played a significantly greater contribution during the dry season. The coral reef enhanced the dominant oceanic $F_{\mathrm{DMS}}$ by $4 \%$ during the wet season and $14 \%$ during the dry season campaign, where the dry season flux enhancement resulted largely from the $45.9 \mathrm{nmol} \mathrm{m}^{-3} \mathrm{DMS}_{\mathrm{a}}$ spike generated by a rain rate of only $1.5 \mathrm{~mm} \mathrm{~h}^{-1}$ onto the aerially exposed coral reef at low tide. Clearly, considerable uncertainty is inherent in the estimated coral reef DMS flux due to the difficulty of distinguishing the coral reef and oceanic $\mathrm{DMS}_{\mathrm{a}}$ source contributions; however, it provides a starting point for future improvement.

\section{Conclusions}

This study has provided environmental evidence that coral reefs in the vicinity of Heron Island are point sources of $\mathrm{DMS}_{\mathrm{a}}$, where emissions may at times be detectable as spikes of DMS ${ }_{\mathrm{a}}$ above the background oceanic signal. Detection of these $\mathrm{DMS}_{\mathrm{a}}$ spikes relies on extended continuous measurements with sufficient frequency to resolve the spikes from the background source signal. The automated GC used here has served that purpose; however, further on-site continuous sampling of DMS $\mathrm{a}_{\mathrm{a}}$ at the GBR is required to more closely examine factors that cause coral reefs to emit DMS to the atmosphere. For example, the higher temporal resolution possible with proton transfer reaction mass spectrometry (Lawson et al., 2011) and atmospheric pressure chemical ionisation mass spectrometry (Bell et al., 2013) may provide additional insights into those factors and their interaction, while also improving the estimation of $F_{\mathrm{DMS}}$ from the GBR. We found the ocean to be the dominant source of $\mathrm{DMS}_{\mathrm{a}}$ at Heron Island, where the ocean source was supplemented by occasional coral-reef-derived spikes of $\mathrm{DMS}_{\mathrm{a}}$ that were highly variable irregular events generally occurring at low tide when conditions exist that can stress the reef. The extreme $\mathrm{DMS}_{\mathrm{a}}$ reef spike recorded in the dry season of 2013, which we conclude was an acute biological response to suddenly unfavourable environmental conditions, demonstrates that the Heron Island lagoonal platform reef has a unique DMS emission mechanism when compared with the surface ocean, where wind driven turbulence largely controls the air-sea exchange of DMS. Furthermore, the extreme $\mathrm{DMS}_{\mathrm{a}}$ spike in the winter dry season demonstrates that the Heron Island lagoonal platform reef can be a seasonally aberrant source of $\mathrm{DMS}_{\mathrm{a}}$ in comparison to the surface ocean, where increased primary production in the summer provides consistently higher concentrations of $\mathrm{DMS}_{\mathrm{a}}$ than the dormant winter period (Ayers et al., 1991). The seasonal aberration of the coral reef as a source of $\mathrm{DMS}_{\mathrm{a}}$ is supported by the flux estimates, where the coral reef enhanced the dominant oceanic $F_{\mathrm{DMS}}$ by $14 \%$ during the dry season but only $4 \%$ during the wet season campaign. Another significant finding from this study is that convective precipitation intensified the low-tide emission of DMS from the coral reef surrounding Heron Island. On a broader regional scale this process may contribute to sulfatederived secondary aerosol that may ultimately influence the radiation budget over the GBR; however, the extent to which $\mathrm{DMS}_{\mathrm{a}}$ contributes to aerosol production and its role in CCN formation over the GBR is currently unknown. Aerosol formation and evolution studies are, therefore, required to determine whether the GBR is a climatically influential source of marine aerosol.

\section{Data availability}

The data presented in this research article are available online at doi:10.4226/47/58781bbfca619 (Swan, 2017) and are located in Southern Cross University's ePublications@SCU data repository, http://epubs.scu.edu.au/data collections/. The goal of this digital repository, managed by 
Southern Cross University Library, is to capture and preserve the intellectual output of Southern Cross University authors and researchers, and to increase visibility and impact through open access to researchers around the world.

Author contributions. Hilton B. Swan configured the instrumentation; collected, processed, and interpreted the data; and wrote the manuscript, gaining edits and textual contributions from the coauthors. Graham B. Jones initiated the field study program and, together with Elisabeth S. M. Deschaseaux, participated in some of the field work to assist in data collection. All authors approved the study design.

Competing interests. The authors declare that they have no conflict of interest.

Acknowledgement. This research was funded from grants to G.B. Jones by the Marine Ecology Research Centre of Southern Cross University (SCU), the Australian Institute for Marine Science (AIMS, Townsville, Qld), and the Australian Research Council Discovery Program (ARCDP) DP140100681. Additional funding was provided from ARCDP grants DP110103638 and DP160100248 awarded to Bradley D. Eyre. Hilton B. Swan would like to thank George Tannous for constructing the autosampler, the National Measurement Institute Australia for providing some of the equipment used to collect the DMS $\mathrm{S}_{\mathrm{a}}$ datasets, Edith Swan for assistance with preparation of graphics, and John Ivey for helpful comments on the manuscript. All authors would like to thank the Heron Island Research Station staff and management for assisting with our experimental needs, and Melissa MacKeller (University of Queensland) for providing Fig. 1b. We gratefully acknowledge the NOAA Air Resources Laboratory (ARL) for provision of the HYSPLIT transport and dispersion model and READY website (http://www.ready.noaa.gov) used to obtain back trajectories and mixed layer heights.

Edited by: G. Herndl

Reviewed by: two anonymous referees

\section{References}

Andreae, M. O. and Raemdonck, H.: Dimethyl sulfide in the surface ocean and the marine atmosphere: a global view, Science, 221, 744-747, 1983.

Ayers, G. P. and Gillett, R. W.: DMS and its oxidation products in the remote marine atmosphere: implications for climate and atmospheric chemistry, J. Sea Res., 43, 275-286, 2000.

Ayers, G. P., Ivey, J. P., and Gillett, R. W.: Coherence between seasonal cycles of dimethylsulphide, methanesulphonate and sulphate in marine air, Nature, 329, 404-406, 1991.

Ayers, G. P., Gillett, R. W., Ivey, J. P., Schäfer, B., and Gabric, A.: Short-term variability in marine atmospheric dimethylsulfide concentration, Geophys. Res. Lett., 22, 2513-2516, 1995.
Barnard, W. R., Andreae, M. O., Watkins, W. E., Bingemer, H., and Georgii, H.-W.: The flux of dimethylsulfide from the oceans to the atmosphere, J. Geophys. Res., 87, 8787-8793, 1982.

Bell, T. G., De Bruyn, W., Miller, S. D., Ward, B., Christensen, K. H., and Saltzman, E. S.: Air-sea dimethylsulfide (DMS) gas transfer in the North Atlantic: evidence for limited interfacial gas exchange at high wind speed, Atmos. Chem. Phys., 13, 1107311087, doi:10.5194/acp-13-11073-2013, 2013.

Broadbent, A. D. and Jones, G. B.: DMS and DMSP in mucus ropes, coral mucus, surface films and sediment pore waters from coral reefs in the Great Barrier Reef, Mar. Freshwater Res., 55, 849855, 2004.

Broadbent, A. and Jones, G.: Seasonal and diurnal cycles of dimethylsulfide, dimethylsulfoniopropionate and dimethylsulfoxide at One Tree Reef lagoon, Environ. Chem., 3, 260-267, 2006.

Charlson, R. J., Lovelock, J. E., Andreae, M. O., and Warren, S. G.: Oceanic phytoplankton, atmospheric sulphur, cloud albedo and climate, Nature, 326, 655-661, 1987.

Chen, G., Davis, D., Kasibhatla, P., Bandy, A., Thornton, D., and Blake, D.: A mass-balance/photochemical assessment of DMS sea-to-air flux as inferred from NASA GTE PEM-West A and B observations, J. Geophys. Res., 104, 5471-5482, 1999.

Cheskis, S., Atar, E., and Amirav, A.: Pulsed-flame photometer: A novel gas chromatography detector, Anal. Chem., 65, 539-555, 1993.

Clarke, A. D., Varner, J. L., Eisele, F., Mauldin, R. L., Tanner, D., and Litchy, M.: Particle production in the remote marine atmosphere: Cloud outflow and subsidence during ACE1, J. Geophys. Res., 103, 16397-16409, 1998.

Deschaseaux, E. S. M., Jones, G. B., Deseo, M. A., Shepherd, K. M., Kiene, R. P., Swan, H. B., Harrison, P. L., and Eyre, B. D.: Effects of environmental factors on dimethylated sulphur compounds and their potential role in the antioxidant system of the coral holobiont, Limnol. Oceanogr., 59, 758-768, 2014.

Eyre, B. D., Santos, I. R., and Maher, D. T.: Seasonal, daily and diel $\mathrm{N}_{2}$ effluxes in permeable carbonate sediments, Biogeosciences, 10, 2601-2615, doi:10.5194/bg-10-2601-2013, 2013.

Finlayson-Pitts, B. J. and Pitts Jr., J. N.: Chemistry of the Upper and Lower Atmosphere: Theory, Experiments, and Applications, Academic Press, San Diego, USA, 2000.

Fischer, E. and Jones, G.: Atmospheric dimethylsulphide production from corals in the Great Barrier Reef and links to solar radiation, climate and coral bleaching, Biogeochemistry, 110, 31-46, 2012.

Harrison, E. L., Veron, F., Ho, D. T., Reid, M. C., Orton, P., and McGillis, W. R.: Nonlinear interaction between rain- and windinduced air-water gas exchange, J. Geophys. Res., 117, 1-16, 2012.

Ho, D. T. and Wanninkhof, R.: Air-sea gas exchange in the North Atlantic: ${ }^{3} \mathrm{He}_{\mathrm{SSF}}$ experiment during GasEx-98, Tellus B, 68, 30198, doi:10.3402/tellusb.v68.30198, 2016.

Hopkins, F. E., Bell, T. G., Yang, M., Suggett, D. J., and Steinke, M.: Air exposure of coral is a significant source of dimethylsulfide (DMS) to the atmosphere, Scientific Reports, 6, 36031, 2016.

Huebert, B. J., Blomquist, B. W., Yang, M. X., Archer, S. D., Nightingale, P. D., Yelland, M. J., Stephens, J., Pascal, R. W., and Moat, B. I.: Linearity of DMS transfer coefficient with both fric- 
tion velocity and wind speed in the moderate wind speed range, Geophys. Res. Lett., 37, 1-5, 2010.

Hutchings, P., Kingsford, M. J., and Hoegh-Guldberg, O.: The Great Barrier Reef: Biology, Environment and Management, CSIRO Publishing, Collingwood, Victoria, 2008.

Johnson, R. H., Ciesielski, P. E., and Cotturone, J. A.: Multiscale variability of the atmospheric mixed layer over the western Pacific warm pool, J. Atmos. Sci., 58, 2729-2750, 2001.

Jones, G. B. and Trevena, A. J.: The influence of coral reefs on atmospheric dimethylsulphide over the Great Barrier Reef, Coral Sea, Gulf of Papua and Solomon and Bismarck Seas, Mar. Freshwater Res., 56, 85-93, 2005.

Kirst, G. O.: Osmotic adjustment in phytoplankton and macroalgae: the use of dimethylsulfoniopropionate (DMSP), in: Biological and Environmental Chemistry of DMSP and Related Sulfonium Compounds, edited by: Kiene, R. P., Visscher, P. T., Keller, M. D., and Kirst, G. O., Plenum Press, New York, 1996.

Kittler, P., Swan, H., and Ivey, J.: An indicating oxidant scrubber for the measurement of atmospheric dimethylsulphide, Atmos. Environ. A-Gen., 26, 2661-2664, 1992.

Lana, A., Bell, T. G., Simó, R., Vallina, S. M., Ballabrera-Poy, J., Kettle, A. J., Dachs, J., Bopp, L., Saltzman, E. S., Stefels, J., Johnson, J. E., and Liss, P. S.: An updated climatology of surface dimethylsulfide concentrations and emission fluxes in the global ocean, Global Biogeochem. Cy., 25, 1-17, 2011.

Lawson, S., Galbally, I., Dunne, E., and Gras, J.: Measurement of VOCs in marine air at Cape Grim using proton transfer reactionmass spectrometry (PTR-MS), in: Baseline Atmospheric Program Australia 2007-2008, edited by: Derek, N. and Krummel, P. B., Commonwealth of Australia, Melbourne, 2011.

MacKellar, M. C., McGowan, H. A., Phinn, S. R., and Soderholm, J. S.: Observations of the surface energy fluxes and boundarylayer structure over Heron Reef, Great Barrier Reef, Australia, Bound.-Lay. Meteorol., 146, 319-340, 2013.

McGowan, H. A., Sturman, A. P., MacKellar, M. C., Wiebe, A. H., and Neil, D. T.: Measurements of the local energy balance over a coral reef flat, Heron Island, southern Great Barrier reef, Australia, J. Geophys. Res., 115, 1-12, 2010.

Modini, R. L., Ristovski, Z. D., Johnson, G. R., He, C., Surawski, N., Morawska, L., Suni, T., and Kulmala, M.: New particle formation and growth at a remote, sub-tropical coastal location, Atmos. Chem. Phys., 9, 7607-7621, doi:10.5194/acp-9-7607-2009, 2009.

Quinn, P. K. and Bates, T. S.: The case against climate regulation via oceanic phytoplankton sulphur emissions, Nature, 480, 5156, 2011.

Rohrer, F. and Berresheim, H.: Strong correlation between levels of tropospheric hydroxyl radicals and solar ultraviolet radiation, Nature, 442, 184-187, 2006.

Saltzman, E. S., King, D. B., Holmen, K., and Leck, C.: Experimental determination of the diffusion coefficient of dimethylsulfide in water, J. Geophys. Res., 98, 16481-16486, 1993.

Seinfeld, J. H. and Pandis, S. N.: Atmospheric Chemistry and Physics, John Wiley \& Sons Inc, New York, 1998.

Shon, Z.-H., Kim, K.-H., Swan, H., Lee, G., and Kim, Y.-K.: DMS photochemistry during the Asian dust-storm period in the Spring of 2001: model simulations vs. field observations, Chemosphere, 58, 149-161, 2005.
Stefels, J.: Physiological aspects of the production and conversion of DMSP in marine algae and higher plants, J. Sea Res., 43, 183197, 2000.

Stein, A. F., Draxler, R. R., Rolph, G. D., Stunder, B. J. B., Cohen, M. D., and Ngan, F.: NOAA's HYSPLIT atmospheric transport and dispersion modeling system, B. Am. Meteorol. Soc., 96, 2059-2077, 2015.

Stull, R. B.: An Introduction to Boundary Layer Meteorology, Kluwer Academic Publishers, Dordrecht, the Netherlands, 1988.

Swan, H. B., Ivey, J. P., Jones, G. B., and Eyre, B. D.: The validation and measurement uncertainty of an automated gas chromatograph for marine studies of atmospheric dimethylsulfide, Anal. Meth., 7, 3893-3902, 2015.

Swan, H. B., Crough, R. W., Vaattovaara, P., Jones, G. B., Deschaseaux, E. S. M., Eyre, B. D., Milijevic, B., and Ristovski, Z. D.: Dimethyl sulfide and other biogenic organic compound emissions from branching coral and reef seawater: Potential sources of secondary aerosol over the Great Barrier Reef, J. Atmos. Chem., 73, 303-328, 2016a.

Swan, H. B., Deschaseaux, E. S. M., Jones, G. B., and Eyre, B. D.: Quantification of dimethylsulfoniopropionate (DMSP) in Acropora spp. of reef-building coral using mass spectrometry with deuterated internal standard, Anal. Bioanal. Chem., doi:10.1007/s00216-016-0141-5, online first, 2016b.

Swan, H. B.: Data from: Atmospheric dimethylsulfide surface concentrations at Heron Island $\left(23.44^{\circ} \mathrm{S}, 151.91^{\circ} \mathrm{E}\right)$ on the southern Great Barrier Reef during 6-20 March 2012, and 18 July-5 August 2013, Southern Cross University, doi:10.4226/47/58781bbfca619, 2017.

Thimijan, R. W. and Royal, H. D.: Photometric, radiometric and quantum light units of measure: A review of procedures for interconversion, HortScience, 18, 818-822, 1982.

Vaattovaara, P., Swan, H. B., Jones, G. B., Deschaseaux, E., Miljevic, B., Laaksonen, A., and Ristovski, Z. D.: The contribution of sulfate and oxidized organics in climatically important ultrafine particles at a coral reef environment, International Journal of Environmental, Chemical, Ecological, Geological and Geophysical Engineering, 7, 720-724, 2013.

Vaisala: Humidity Conversion Formulas, Vaisala Oyj Helsinki, Finland, 2013.

Wang, Q., Lenschow, D. H., Pan, L., Schillawski, R. D., Kok, G. L., Prevot, A. S. H., Laursen, K., Russell, L. M., Bandy, A. R., Thornton, D. C., and Suhre, K.: Characteristics of the marine boundary layers during two Lagrangian measurement periods. 2. Turbulence structure, J. Geophys. Res., 104, 21767-21784, 1999.

Wild, C., Huettel, M., Klueter, A., Kremb, S. G., Rasheed, M. Y. M., and Jorgensen, B. B.: Coral mucus functions as an energy carrier and particle trap in the reef ecosystem, Nature, 428, 66-70, 2004

Yang, M., Blomquist, B. W., Fairall, C. W., Archer, S. D., and Huebert, B. J.: Air-sea exchange of dimethylsulfide in the Southern Ocean: Measurements from SO GasEx compared to temperate and tropical regions, J. Geophys. Res., 116, 1-17, 2011. 